\title{
New records amplify the geographical distribution of Rondonops biscutatus Colli et al., 2015 (Squamata, Sauria, Gymnophthalmidae) into the Paraguay river basin, Mato Grosso, Brazil
}

\author{
Odair Diogo da Silva ${ }^{1,2,3}$, Thatiane Martins da Costa ${ }^{2,3,4}$, Vancleber Divino Silva-Alves ${ }^{2,4}$, \\ Eder Correa Fermiano ${ }^{1}$, Jessica Rhaiza Mudrek ${ }^{2,5}$, Bruno Ramos Brum ${ }^{2,4}$, Almério Câmara \\ Gusmão $^{2,3,6}$, Olinda Maira Alves Nogueira ${ }^{2}$, Ana Paula Dalbem Barbosa ${ }^{2,4}$, Joselaine Souto Hall \\ $\mathrm{Silva}^{2,4}$, Maria Antônia Carniello ${ }^{2,4}$, Áurea Regina Alves Ignácio ${ }^{2,4}$, Claumir César Muniz ${ }^{2,4}$, \\ Manoel Dos Santos Filho ${ }^{2,4,6}$, Dionei José da Silva ${ }^{1,2,4}$
}

\begin{abstract}
1 Programa de Pós-Graduação em Ambiente e Sistemas de Produção Agrícola, Universidade do Estado de Mato Grosso. Rod. MT 358 Km 07 , Caixa Postal 287, Jardim Aeroporto CEP 78.300-000, Tangará da Serra, MT, Brazil. 2 Rede Erosão da Biodiversidade no Pantanal, Universidade do Estado de Mato Grosso, Av. Santos Dumont, s/nº, Cidade Universitária (Bloco II), CEP 78200-000, Cáceres, MT, Brazil. 3 Grupo de Trabalho e Conservação do Gavião Real no Estado de Rondônia, Brazil. 4 Programa de Pós-Graduação em Ciências Ambientais, Universidade do Estado de Mato Grosso, Centro de Pesquisa de Limnologia, Biodiversidade, Etnobiologia do Pantanal, Av. Santos Dumont, s/nº, Cidade Universitária (Bloco II), CEP 78200-000, Cáceres, MT, Brazil. 5 Programa de Pós-Graduação em Ecologia e Conservação da Biodiversidade, Instituto de Biociências, Universidade Federal de Mato Grosso, Av. Fernando Corrêa, № 2367, Bairro Boa Esperança, CEP 78060-900, Cuiabá, MT, Brazil. 6 Programa de Pós-Graduação em Biotecnologia e Biodiversidade, Rede Bionorte, Universidade do Estado de Mato Grosso. Av. Santos Dumont, s/n $\mathrm{n}^{\circ}$, Cidade Universitária (Bloco II), CEP 78200-000, Cáceres, MT, Brazil.
\end{abstract}

Corresponding author: Odair Diogo da Silva, odair_diogo@hotmail.com

\begin{abstract}
Rondonops biscutatus is a gymnophthalmid litter-lizard which occurs in the Amazon rainforests and the transitional areas between Amazonia and Cerrado. This species' distribution is strongly biased by a lack of data, possibly because it was recently described, small-bodied, and living in cryptic habits. Here, we present occurrence data of six specimens from four locations in transitional areas between forests in Amazonia and Cerrado (central Brazil), in the upper Paraguay River, at the northern end of the Pantanal, midwestern Brazil. We expand the distribution of this species $507 \mathrm{~km}$ east from its original range.
\end{abstract}

\section{Keywords}

Amazon rainforest, biogeography, Cerrado, Iphisini, reptiles.

Citation: Silva-Diogo O, Costa TM, Silva-Alves VD, Fermiano EC, Mudrek JR, Brum BR, Gusmão AC, Nogueira OMA, Barbosa APD, Silva JSH, Carniello MA, Ignácio ÁRA, Muniz CC, Santos-Filho M, Silva DJ (2019) New records amplify the geographical distribution of Rondonops biscutatus Colli et al., 2015 (Squamata, Sauria, Gymnophthalmidae) into the Paraguay river basin, Mato Grosso, Brazil. Check List 15 (5): $747-751$. https://doi.org/10.15560/15.5.747 


\section{Introduction}

The squamate family Gymnophthalmidae contains 258 species (Uetz 2019) distributed from southern Mexico and Central America, including some islands in the Caribbean and South America, to the central portion of Argentina (Doan 2003; Vitt and Caldwell 2009; Cacciali et al. 2017; Mora et al. 2019). Despite their wide distribution and high number of species, the gymnophthalmids are among the least known Neotropical lizards given their cryptic habits and small body size (Cacciali et al. 2017).

The genus Rondonops (Colli et al. 2015), a member of the tribe Iphisini, contains two species that occur in the Amazonian forests of Brazil: Rondonops biscutatus Colli et al. (2015) and Rondonops xanthomystax Colli et al. (2015). Rondonops xanthomystax occurs in the states of Amazonas and Pará (Colli et al. 2015; Costa and Bernils 2018), whereas Rondonops biscutatus has a wider distribution, occurring in the states of Rondônia, Pará, and Mato Grosso, and the distribution of this species covers the Amazon and Araguaia-Tocantins basins (Colli et al. 2015; Abegg et al. 2017; Costa and Bernils 2018). The genus Rondonops was recently described (Colli et al. 2015), although $R$. biscutatus was earlier cited as "Gymnophthalmidae sp." (Gainsbury and Colli 2003; Garda et al. 2013) and "Colobosaura sp. nov." (Hoogmoed et al. 2007).

Despite the recent description of $R$. biscutatus, there are few studies on its biological and ecological traits. This species mainly occupies the leaf-litter (Colli et al. 2015) at sites with a relatively great abundance of small trees, low canopy, dense understory with a few trunks, a high density of termite nests, and few large trees (Garda et al. 2013). Cacciali et al. (2017), when evaluating the phylogeny of the tribe Iphisini, proposed that the genus Rondonops is restricted to Amazonian ecoregions. Furthermore, Colli et al. (2015) and Abegg et al. (2017) suggested that $R$. biscutatus might also occur in forests and open habitats in the transitional area between the Amazon and the Cerrado savannas. In this study, we confirm this prediction based on four new occurrences in the Paraguay river basin, where we collected a total of six specimens in Amazonian phytophysiognomy in Amazon-Cerrado savannas transition area.

\section{Methods}

We collected specimens using 12 sets of pitfall traps in seasonally flooded forests at four sites along the Paraguay River, in the municipality of Barra do Bugres $\left(15^{\circ} 05^{\prime} 42^{\prime \prime} \mathrm{S}, 057^{\circ} 14^{\prime} 30^{\prime \prime} \mathrm{W}, \mathrm{DMS}\right)$, Mato Grosso state. At each point, we installed three sets of Y-shaped pitfall traps, each composed of four $60 \mathrm{~L}$ buckets, which were buried within $15 \mathrm{~m}$ from the central bucket. The buckets were interconnected by a $70 \mathrm{~cm}$ high fence. In each site, we installed pitfall traps along a gradient of distance from the riverbank, at 10, 100 and $200 \mathrm{~m}$. The traps remained open from September 29, 2017 to October 8,2017 , totaling 480 bucket nights of sampling effort.

We euthanized voucher specimens by injection of $2 \%$ lidocaine hydrochloride (Xylestesin $\AA$ ) and preserved them using $10 \%$ formalin. We conserved the voucher specimens in $70 \%$ ethanol and deposited them at the Centro de Limnologia, Biodiversidade e Etnobiologia do Pantanal (CELBE), at the Universidade do Estado de Mato Grosso (UNEMAT), Brazil. We collected specimens under the permanent license 8849-1 and expedition registration 10128, granted by the Sistema de Autorização e Informação em Biodiversidade (SISBIO). Also, we performed a review of three specimens, identified as Colobosaura modesta, collected by Silva (2005) in forest fragments in Amazon, in the Cabaçal and Jauru river basins, which are tributaries of the Paraguay River, in the Northern Pantanal. These specimens were collected in 2003 using pitfall traps and were deposited in the collection of CELBE/UNEMAT and INPA, Manaus. We used a digital caliper and a stereoscopic microscope to measure and count diagnostic characters, in order to identify specimens based on the original description of R. biscutatus (Colli et al. 2015).

\section{Results}

\section{Rondonops biscutatus Colli et al., 2015}

We collected six specimens of $R$. biscutatus from four locations in a transitional region between the Amazon forests and Cerrado savannas. We found three specimens in the municipality of Barra do Bugres, one in Figueirópolis d'Oeste, and two in São José dos Quatro Marcos, all of them near the banks of the upper Paraguay River (Fig. 1).

New Records. Brazil, Mato Grosso, Barra do Bugres Municipality: ecotone between Amazonia and Cerrado, on the left bank of the Paraguay River $\left(15^{\circ} 05^{\prime} 44.30^{\prime \prime} \mathrm{S}\right.$, $\left.057^{\circ} 14^{\prime} 23.52^{\prime \prime} \mathrm{W}\right), 1$ adult male (CELBE-L-0050, $53 \mathrm{~mm}$ SVL, femoral pores 18) collected on 6 October 2017 by Odair D. da Silva, Vancleber DS Alves, and Manoel dos S. Filho (Fig. 2).

Brazil, Mato Grosso, Barra do Bugres Municipality: ecotone between Amazonia and Cerrado, on the right bank of the Paraguay River $\left(15^{\circ} 05^{\prime} 40.03^{\prime \prime} \mathrm{S}\right.$, $\left.057^{\circ} 14^{\prime} 34.71^{\prime \prime} \mathrm{W}\right), 2$ adult females (CELBE-L-0026 and CELBE-L-0031, 48 and $47 \mathrm{~mm}$ SVL) collected on 30 September 2017 by Odair D. da Silva, Thatiane M. da Costa, and Dionei J. da Silva (Fig. 2).

Brazil, Mato Grosso, Figueirópolis d'Oeste Municipality: Amazon forest on the right bank of the Jauru River $\left(15^{\circ} 31^{\prime} 00.35^{\prime \prime} \mathrm{S}, 058^{\circ} 38^{\prime} 29.21^{\prime \prime} \mathrm{W}\right), 1$ adult female (INPA-H 15994, 43 mm SVL), collected by Dionei J. da Silva and Manoel dos S. Filho on 21 February 2003.

Brazil, Mato Grosso, São José dos Quatro Marcos Municipality: Amazon forest on the right bank of the Cabaçal River $\left(15^{\circ} 22^{\prime} 43.86^{\prime \prime} \mathrm{S}, 058^{\circ} 04^{\prime} 34.46^{\prime \prime} \mathrm{W}\right), 2$ adult males, 1 collected by Dionei J. da Silva on 29 January 


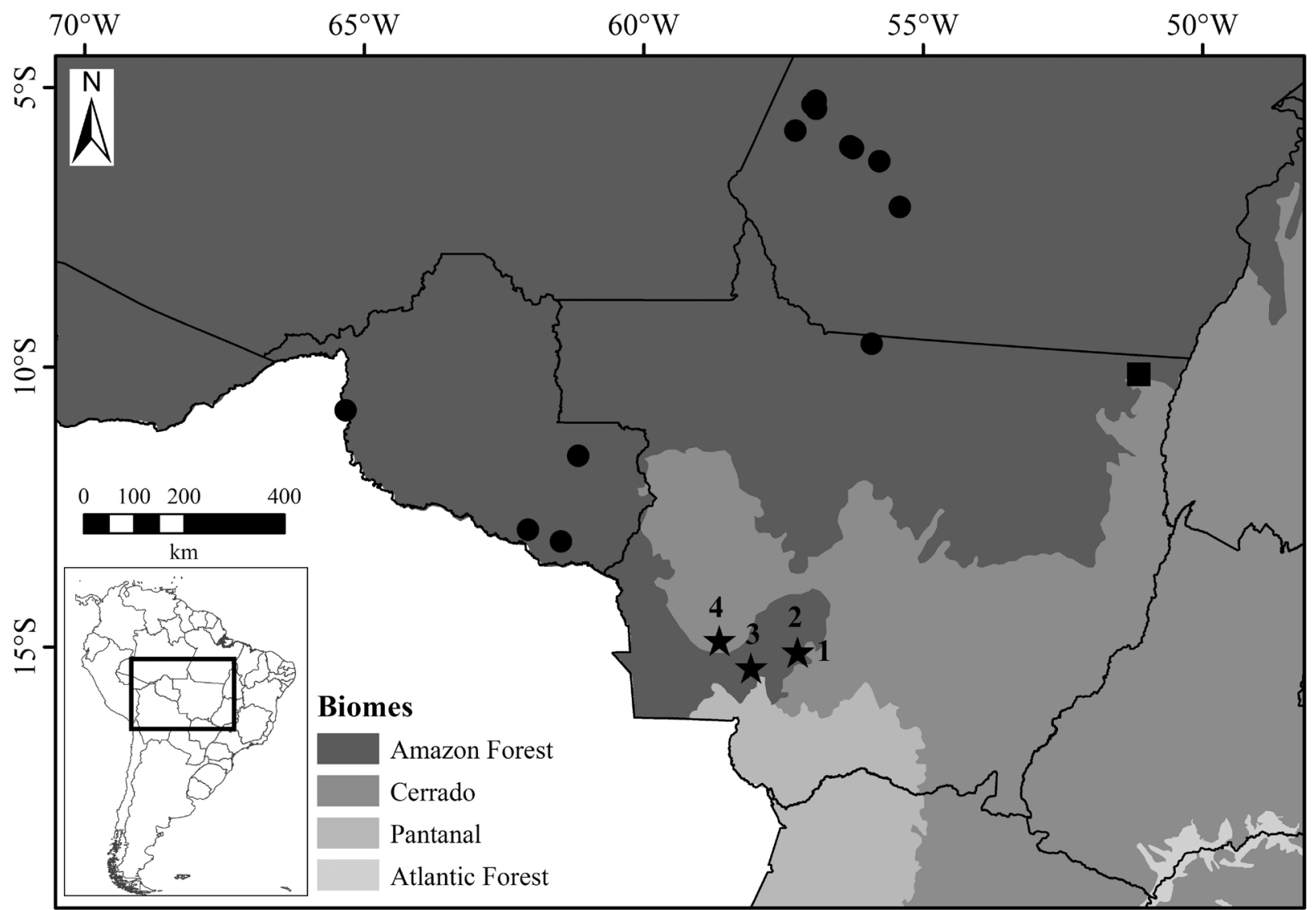

Figure 1. Geographical distribution of Rondonops biscutatus. Circles: Colli et al. (2015); square: Abegg et al. (2017); stars: 1, 2 = Barra do Bugres, 3 = Quatro Marcos, 4 = Figueirópolis d'Oeste.
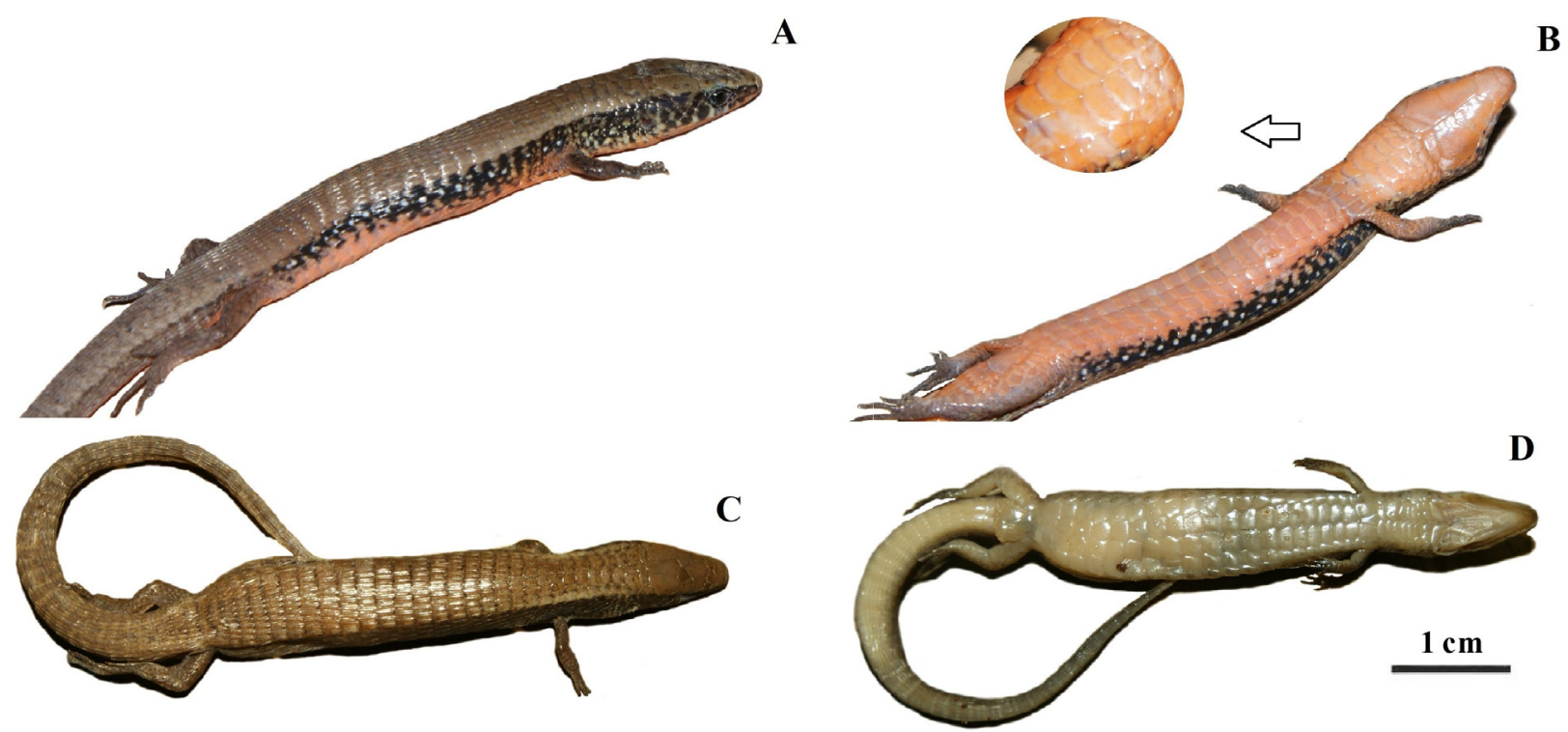

Figure 2. Rondonops biscutatus recorded in Barra do Bugres, Mato Grosso. A, B. Adult male (CELBE-L-0050): color in life, SVL $53 \mathrm{~mm}$, Femoral pores 18: (A) dorsolateral view; (B) ventral view, gular region highlighted, with diagnostic characteristic of the species, two rows of wide ventral scales. C, D. Adult female (CELBE-L-0031), color in alcohol, SVL $47 \mathrm{~mm}$ : (C) dorsolateral view; (D) ventral view.

2003 (CELBE-L-MZT 123, 38mm SVL), and 1 collected by Manoel dos S. Filho on 5 August 2003 (INPA - H 15995, $46 \mathrm{~mm} \mathrm{SVL).}$

Identification. We identified specimens based on the original description of the genus and species (Colli et al. 2015), in which Rondonops was described as easily distinguishable from any other gymnophthalmid lizards. The specimens we found show conspicuous diagnostic characters, such as two longitudinal rows of very wide nuchal scales, extending from the nape to the arm. This extension includes seven smooth and imbricated transverse scales followed by much narrower, lanceolate and mucronate scales (Fig. 1). Rondonops biscutatus also 
differs from the other Gymnophthalmidae genus, except for Iphisa, by having only two rows of very wide ventral scales. Rondonops biscutatus can be distinguished from Rondonops xanthomystax by its smooth scales on the sides of its neck (keeled in $R$. xanthomystax). Additionally, $R$. xanthomystax presents a wide black stripe covering the entire lateral surface of the head in the superior region of the supralabial, which is absent in $R$. biscutatus, and dark-brown supralabials contrasting with the bright yellow-orange color covering most of the supralabials, infralabials, and ventral parts of the head, while in $R$. biscutatus the supralabials are strongly mottled with dark brown.

\section{Discussion}

The description of $R$. biscutatus is relatively recent, and few data on geographic distribution and morphological variation have been reported in the literature. Although the vegetation cover in our study area differed between Cerrado, Amazonia, Pantanal and ecotonal zones (Maurão et al. 2012), we only found the species in an area with Amazonian phytophysiognomy. Thus, our records, indicate that the species is restricted to Amazonian phytophysiognomies, which is consistent with the opinions of Colli et al. (2015), Abegg et al. (2017) and Cacciali et al. (2017). This conclusion is supported by the fact that we have sampled lizards across approximately 200 $\mathrm{km}$ along the upper Paraguay River, from the Barra do Bugres $\left(15^{\circ} 05^{\prime} 41.66^{\prime \prime} \mathrm{S}, 057^{\circ} 14^{\prime} 30.08^{\prime \prime} \mathrm{W}\right)$ to the Taiamã Ecological Station (16 $\left.51^{\prime} 54.20^{\prime \prime} \mathrm{S}, 057^{\circ} 33^{\prime} 11.52^{\prime \prime} \mathrm{W}\right)$. Although this ecotonal region is environmentally very heterogeneous, the species has only been found in Amazonian forests characterized by tall trees $(>20 \mathrm{~m})$, few epiphytes, relatively distant trees and low abundance of lianas. The understory is dense, with up to $10 \mathrm{~cm}$ of leaf litter.

Our records extend the geographical range of $R$. biscutatus $507 \mathrm{~km}$ southeast from the southernmost previous record at Cerejeiras, Rondônia. However, we argue that the species distribution does not extend further east into the Cerrado savannas, because the low canopy in the Cerrado savannas is often associated with open understory and high solar incidence, which are suboptimal conditions for a litter lizard such as $R$. biscutatus.

A portion of the range of $R$. biscutatus, in the north, is within protected reserves. However, most of the species' distribution is currently undergoing habitat loss due to strong anthropological changes (Colli et al. 2015; Abegg et al. 2017), especially within the so-called arch of deforestation (Ferreira et al. 2005). In this region, human occupation has resulted in a matrix of monocultures of grains and pastures for cattle ranching associated with or preceded by illegal logging (Fearnside 2010). Likewise, the upper Paraguay River region, where the new records originate, is strongly influenced by soybean monoculture in the headwaters of the river and by the production of sugarcane and cattle ranching where large amounts of pesticides are used (Tomas 2009). Thus, R. biscutatus is under pressure of habitat loss and degradation, as are many Brazilian reptiles, mainly caused by agribusiness activities and the use of agrochemicals, which have been pointed out as the main risk factor for reptiles (Gibbons et al. 2000; Rodrigues 2005; ICMbio 2018).

\section{Acknowledgements}

The development of this research was possible through the project "Erosão da biodiversidade na Bacia do Alto Paraguai: impactos do uso da terra na estrutura da vegetação e comunidade de vertebrados terrestres e aquáticos", which has financial support from FAPEMAT (edictal no. 037/2016, Research Networks in Mato Grosso with concession term under no. 0589188/2016). We thank Guarino R. Colli for the contributing to the identification of the species. We thank the field staff of the Erosion project. We also thank the Coordenação de Aperfeiçoamento de Pessoal de Nível Superior (CAPES; code 001) for the scholarships provided to the authors $\mathrm{BRB}$ and $\mathrm{ACG}$ and for the masters scholarships provided to the authors ODS, OMAN, ECF, APDB, and TMC. We thank the Foundation Mato Grosso State Research Support Service (FAPEMAT) for VDSA's scholarship and the doctoral scholarship provided to JRM.

\section{Authors' Contributions}

ODS, VDSA, TMC, JRM, OMAN, APDB, MAC, CCM, MSF and DJS collected the specimens. ODS, VDSA, ACG, ECF and DJS analyzed the specimens and wrote the first version of the manuscript. JRM produced the distribution map. BRB, ARAI and DJS revised and translated the final version.

\section{References}

Abegg AD, Entiauspe-Neto OM, Santos FPR, Borges LM (2017) A new record of Rondonops biscutatus (Reptilia, Sauria, Gymnophthalmidae) from Mato Grosso, Brazil. Check List 13 (4): 7-10. https://doi.org/10.15560/13.4.7

Cacciali P, Martínez N, Köhler G (2017) Revision of the phylogeny and chorology of the tribe Iphisini with the revalidation of Colobosaura kraepelini Werner, 1910 (Reptilia, Squamata, Gymnophthalmidae). ZooKeys 669: 89-105. https://doi.org/10.3897/zoo keys.669.12245

Colli GR, Hoogmoed MS, Cannatella DC, Cassimiro J, Gomes JO, Ghellere JM, Nunes PMS, Pellegrino KCM, Salerno P, Souza SM, Rodrigues MT (2015) Description and phylogenetic relationships of a new genus and two new species of lizards from Brazilian Amazonia, with nomenclatural comments on the taxonomy of Gymnophthalmidae (Reptilia: Squamata). Zootaxa 4000: 401427. https://doi.org/10.11646/zootaxa.4000.4.1

Costa HC, Bérnils RS (2018) Répteis do Brasil e suas Unidades Federativas: Lista de espécies. Herpetologia Brasileira 7 (1): 1-58.

Doan TM (2003) A new phylogenetic classification for the gymnophthalmid genera Cercosaura, Pantodactylus, and Prionodactylus (Reptilia: Squamata). Zoological Journal of the Linnean Society 137(1): 101-115. https://doi.org/10.1046/j.1096-3642.2003.00043.x

Fearnside PM (2010) Consequências do desmatamento da Amazônia. Scientific American Brasil Especial Biodiversidade 2010: 
$54-59$.

Ferreira LV, Venticinque E, Almeida S (2005) O desmatamento na Amazônia e a importância das áreas protegidas. Estudos Avançados 19: 157-166. https://doi.org/10.1590/s0103-40142005000100010

Gainsbury AM, Colli GR (2003) Lizard assemblages from natural Cerrado enclaves in southwestern Amazonia: the role of stochastic extinctions and isolation. Biotropica 35 (4): 503-519. https:// doi.org/10.1111/j.1744-7429.2003.tb00607.x

Garda AA, Wiederhecker HC, Gainsbury AM, Costa GC, Pyron RA, Vieira GHC, Werneck FP, Colli GR (2013) Microhabitat variation explains local-scale distribution of terrestrial Amazonian lizards in Rondônia, western Brazil. Biotropica 45: 245-252. http://doi. org/10.1111/j.1744-7429.2012.00906.x

Gibbons JW, Scott DE, Ryan TJ, Buhlmann KA, Tuberville TD, Metts BS, Greene JL, Mills T, Leiden Y, Poppy S, Winne CT (2000). The global decline of reptiles, déjà vu amphibians: reptile species are declining on a global scale. Six significant threats to reptile populations are habitat loss and degradation, introduced invasive species, environmental pollution, disease, unsustainable use, and global climate change. BioScience 50 (8): 653-666. https://doi. org/10.1641/0006-3568(2000)050[0653:TGDORD]2.0.CO;2

Hoogmoed MS, Ribeiro-Júnior MA, Araújo CO (2007) Avaliação do estado de conhecimento da herpetofauna na região da BR-163 no estado do Pará. In: Venturieri A (Ed.) Zoneamento Ecológico-econômico da Área de Influência da Rodovia BR-163 (Cuiabá-Santarém). Vol. 2. EMBRAPA Amazônia Oriental, Belém, 143-152.

Instituto Chico Mendes de Conservação da Biodiversidade (2018)
Livro Vermelho da Fauna Brasileira Ameaçada de Extinção: Volume IV-Répteis. In: Instituto Chico Mendes de Conservação da Biodiversidade (Org.) Livro Vermelho da Fauna Brasileira Ameaçada de Extinção. ICMBio, Brasília, 252 pp.

Mourão G, Oliveira MD, Calheiros DF, Padovani CR, Marques EJ, Uetanabaro M (2002). O Pantanal Mato-grossense. In: Seeliger U, Cordazzo C, Barbosa FAR (Eds) Os sites e o Programa Brasileiro de Pesquisas Ecológicas de Longa Duração. Universidade Federal de Minas Gerais, Belo Horizonte, 29-49.

Mora JM, Espinal MR, Chaves, G, López, LI (2019) Distributional records for Loxopholis rugiceps Cope, 1869 (Squamata, Gymnophthalmidae) in Central America. Check List 15 (3): 363-368. https://doi.org/10.15560/15.3.363

Rodrigues MT (2005) Conservação dos répteis brasileiros: os desafios para um país megadiverso. Megadiversidade 1 (1): 87-94.

Silva, DJ (2005) Efeitos da fragmentação sobre a comunidade de lagartos em áreas de Floresta Estacional Semidecidual Submontana no sudoeste de Mato Grosso, Brasil. 107 f. Tese (Doutorado em Ecologia), Instituto Nacional de Pesquisas da Amazônia/ Universidade Federal do Amazonas, Manaus, 98 p.

Tomas WM, Mourão G, Campos Z, Salis SM, Santos SA (2009) Intervenções humanas na paisagem e nos habitats do Pantanal. Embrapa Pantanal, Corumbá, 58 p.

Uetz P, Freed P, Hosek J (Eds) (2019) The Reptile Database. http:// www.reptile-database.org. Accessed on: 2019-05-11.

Vitt LJ, Caldwell J (2009) Herpetology: An Introductory Biology of Amphibians and Reptiles. Academic Press, San Diego, 697 pp. 